Int. J. Electrochem. Sci., 11 (2016) $10391-10406$

\title{
Voltammetric Biosensor Based on a Modified Chitosan Membrane Enzyme Peroxidase
}

\author{
Pavla Martinkova ${ }^{1}$, Miroslav Pohanka ${ }^{1,2, *}$ \\ ${ }^{1}$ Faculty of Military Health Sciences, University of Defense, Trebesska 1575, Hradec Kralove, Czech \\ Republic \\ ${ }^{2}$ Department of Geology and Pedology, Mendel University in Brno, Czech Republic \\ *E-mail: miroslav.pohanka@gmail.com
}

doi: $10.20964 / 2016.12 .64$

Received: 14 September 2016 / Accepted: 10 October 2016 / Published: 10 November 2016

The determination of hydrogen peroxide $\left(\mathrm{H}_{2} \mathrm{O}_{2}\right)$ has a significant meaning in environmental, pharmaceutical, healthcare and food analyses. The current work is focused on construction of a fast but reliable and accurate voltammetric biosensor enabling detection of $\mathrm{H}_{2} \mathrm{O}_{2}$ giving opportunity to its application into practice. This biosensor was based on screen printed electrode covered with chitosan membrane entrapping horseradish peroxidase (HRP), magnetic particles (MPs) and Prussian blue (PB). MPs an inorganic substrate having pseudo-peroxidase activity together with HRP catalyzed reduction of $\mathrm{H}_{2} \mathrm{O}_{2}$ and $\mathrm{PB}$ as mediator of electron transfer enabled highly sensitive detection at low applied potential. Square wave voltammetry (SWV) was chosen as a detection device. Average area peaks of each $\mathrm{H}_{2} \mathrm{O}_{2}$ concentration created calibration curve replying Michaelis-Menten equation with correlation coefficient 0.999 . Limit of detection was equal to $8.2 \mu \mathrm{mol} / 1$ of $\mathrm{H}_{2} \mathrm{O}_{2}$. Uric acid, ascorbic acid, water soluble derivate of vitamin $\mathrm{E}$ (trolox), acetaminophen and reduced glutathione were measured as possibly interfering substances replacing $\mathrm{H}_{2} \mathrm{O}_{2}$ in the reaction and no significant influence on the assay was observed when presented in equivalent concentrations as the $\mathrm{H}_{2} \mathrm{O}_{2}$. Different personal care matrix substances (tooth paste, hand cream and skin tonic) were spiked with $\mathrm{H}_{2} \mathrm{O}_{2}$ and no effect of matrix on the determination was detected. On the basis of the presented results, , the proposed assay was considered to be highly sensitive, accurate and fast assay for detection of $\mathrm{H}_{2} \mathrm{O}_{2}$ so this platform can be applied in wide spectrum of research and clinical fields.

Keywords: Voltammetry; hydrogen peroxide; horseradish peroxidase; Prussian blue; magnetic particles

\section{$\underline{\text { FULL TEXT }}$}

(C) 2016 The Authors. Published by ESG (www.electrochemsci.org). This article is an open access article distributed under the terms and conditions of the Creative Commons Attribution license (http://creativecommons.org/licenses/by/4.0/). 